
2021
Revista Vol. 24(47)
Prolegómenos enero-junio - ISSN: 0121-182x · e-ISSN: 1909-7727 - pp. 55-78

DOI: https://doi.org/10.18359/prole.4722

\title{
Is Consumer Welfare Obsolete? A European Union Competition Perspective
}

\author{
Frédéric Martya
}

\begin{abstract}
European Commission advocated for a more economic approach to enforcing competition laws. The sole criterion for assessing the lawfulness of a market practice should be the appraisal of its net effects on consumer welfare. The Court of Justice was reluctant to adopt such an approach until its 2017 Intel Judgment. Its endorsement-which is debatable insofar as the judgment may give rise to different interpretations-may appear paradoxical in that it is concomitant with a sharp challenge to the consumer welfare criterion in the United States. The purpose of this article is to retrace the history of this criterion, particularly its adoption in the context of EU competition law. We aim to show that the criticisms of the effects-based approach can be addressed not by moving away from the consumer welfare criterion but by integrating it into a broader perspective that also takes into account the protection of the competition process itself.
\end{abstract}

Keywords: anti-competitive practices; effects-based approach; consumer welfare; ordoliberalism; European Union competition law

Received: 13 de abril de $2020 \quad$ Accepted: 09 de febrero de 2021

Available online: 06 de agosto de 2021

How to cite: Marty, F. (2021). Is the Consumer Welfare Obsolete? A European Union Competition Law and Competition Perspective. Prolegómenos, 24(47), 55-78. https://doi.org/10.18359/prole.4722

* Research article.

a PhD in economics, French National Centre for Scientific Research (CNRS) fellow, Research Group on Law, Economics, and Management (GREDEG), Université Côte d'Azur, Valbonne, France.

E-mail: frederic.marty@gredeg.cnrs.fr ORCID: https://orcid.org/0000-0002-9881-2036 


\section{¿Es obsoleto el bienestar del consumidor? Una perspectiva de la competencia en la Unión Europea}

Resumen: en 2005, la Comisión Europea abogó por un enfoque más económico de la aplicación de las leyes de competencia. El único criterio para evaluar la legalidad de una práctica de mercado debe ser la evaluación de sus efectos netos sobre el bienestar de los consumidores. El Tribunal de Justicia se mostró reacio a adoptar este enfoque hasta la sentencia de Intel de 2017. Su aprobación — que es discutible en la medida en que la sentencia puede dar lugar a diferentes interpretaciones- puede parecer paradójica en el medida en que es concomitante con un fuerte desafío al criterio del bienestar del consumidor en los Estados Unidos. La finalidad de este artículo es volver sobre la historia de este criterio, en particular en su adopción en el contexto de la ley de competencia de la UE. Nuestro objetivo es demostrar que las críticas al enfoque basado en los efectos pueden abordarse sin alejarse del criterio de bienestar del consumidor, sino integrándolo en una perspectiva más amplia que también tenga en cuenta la protección del propio proceso de competencia.

Palabras clave: prácticas anticompetitivas; enfoque basado en los efectos; bienestar del consumidor; ordoliberalismo; derecho de la competencia de la Unión Europea

\section{O bem-estar do consumidor se tornou obsoleto? Uma perspectiva de concorrência da União Europeia}

Resumo: em 2005, a Comissão Europeia advogou por uma abordagem mais econômica da aplicação das leis de concorrência. O único critério para avaliar a legalidade de uma prática de mercado deve ser a avaliação de seus efeitos líquidos sobre o bem-estar dos consumidores. O Tribunal de Justiça se mostrou relutante a adotar essa abordagem até a sentença da Intel de 2017. Sua aprovação, que é discutível na medida em que a sentença pode dar espaço a diferentes interpretações, pode parecer paradoxal, visto que é concomitante com um forte desafio para o critério do bem-estar do consumidor nos Estados Unidos. O objetivo deste artigo é voltar à história desse critério, em particular sua adoção no contexto da lei de concorrência da União Europeia. Além disso, demonstrar que as críticas à abordagem baseada nos efeitos podem ser tratadas ao não nos afastarmos do critério de bem-estar do consumidor, mas sim integrando-o numa perspectiva mais ampla que também considere a proteção do próprio processo de concorrência.

Palavras-chave: práticas anticoncorrenciais; abordagem baseada em efeitos; bem-estar do consumidor; ordoliberalismo; direito da concorrência da União Europeia 
As a cornerstone of European Union (hereafter EU) competition law enforcement since the (gradual) adoption of the effects-based approach over the last 15 years, the consumer welfare criterion is paradoxically being challenged at the very moment when it seemed to be gaining ground. This contribution aims to put this dynamic of adoption into perspective with the history of EU competition case law and the history of economic thought.

We show how the debates surrounding the concentration of economic power in the United States (us) and its consequences on competition have led to a re-examination of the place of consumer welfare as the sole criterion for assessing competitive practices. These considerations echo the now secular debates on the Sherman Act's finality and the questions raised by 1930s neo-liberals on both sides of the Atlantic. It is a question of deciding between a competition policy that aims to secure the outcome of competition-allocative efficiency- and a competition policy that aims to protect the competition process for its own sake.

This second option amounts de facto to updating the European concept of the dominant operator's special responsibility for preserving a situation of effective competition. Therefore, it is not a question of rejecting the criterion of consumer welfare but of reconciling objectives that may to some extent be incommensurable and sometimes contradictory: loyalty, fairness, preservation of market access... In the end, it is a matter of the judge's role in applying the rule of law.

This article discusses the place of the consumer welfare criterion and its implementation in competition rules. The first section shows that it was only very belatedly integrated into the framework of EU competition law. The second section highlights that in the face of the challenges posed, particularly in the us, the consumer welfare criterion remains valid from the moment it is integrated into broader competitive reasoning, as implemented by the European Commission. Nevertheless, our conclusion reveals that such a reconciliation between potentially contradictory criteria may not go by itself. Our third and conclusive section discusses the difficulties in implementing a competition protection standard and presents some arguments in defence of the total welfare criterion as an alternative to the consumer welfare one.

\section{A gradual convergence of EU competition law enforcement towards a more economic approach}

This first section highlights how European competition authorities have gradually adopted consumer welfare as the sole criterion for competition rules enforcement, even though the foundations for the construction of European competition policy are based on broader theoretical roots, partly derived from German ordoliberalism¹ ${ }^{1}$.

\section{The historic foundations of the EU competition law}

In this section, we first investigate the history of competition laws to separate the us influence from the European roots of the EU competition policy before considering in a second subsection the concentration of markets in the current antitrust debate.

\section{The European roots of EU competition law}

Historically, the first competition laws were North American. The first competition laws enacted were, more precisely, Canadian ${ }^{2}$ in 1889 and us with the Sherman Act in 1890. Meanwhile, the protection of competition was all but satisfying in the European continent. For instance, in France, the sanction of cartels remained purely hypothetical for a long time. Although the 1810 Penal Code

1 We will therefore assimilate the European approach and ordoliberalism in the rest of the article. The identification of the two is debatable, but it intends to simplify the point. It would also be possible to use the concept of the Brussels School (see Hildebrand, 2012).

2 The Combines Investigation Act, extended to include mergers and monopolisation activities, and consumer protection. See https://www.competitionbureau.gc.ca/eic/site/cb-bc.nsf/eng/03631. html 
had provided legal tools to sanction cartels ${ }^{3}$, the courts, since the Restauration, had made a distinction between good and bad cartels, leading to non-enforcement (Didry \& Marty, 2016). In Germany, the Reichsgericht (the Supreme Court) validated cartel arrangements in 1897 based on freedom of contract (Joliet, 1967). In the same decade, in the United Kingdom, the House of Lords, then sitting as a supreme court, in its Mogul Steamships decision (1892), acquiesced to "predatory" strategies as long as they benefit the consumer and appear to adhere to the principles of free competition ${ }^{4}$. Thus, before 1914, no legislation comparable to the Canadian and us legislation existed in Europe. Gerber (1998) points out that some projects were nevertheless discussed in Austria-Hungary and Sweden on the eve of the First World War. However, these laws were not adopted.

Even worse, the experiences of the war economy caused large corporations and public authorities to consider inter-firm coordination, i.e., cartelisation, as an effective tool for steering the national economy. In this regard, it is instructive to note that the German example strongly influenced the French government during the conflict itself. A reversal is thus taking place in the aftermath of the Great War. The pre-war period was shaped by prevailing classical liberalism. The laissez-faire appeared as the best approach in terms of economic policy. As in other government interventions, competition policy did not have a specific role to play unless

3 Article 419 of the 1810 Penal Code stated, "All those who, by false or slanderous claims deliberately sown in the public, by exaggerating offers at the prices demanded by the sellers themselves, by meetings or coalitions between the principal holders of the same merchandise or commodity, tend not to sell it, or to sell it only at a certain price, or all those who, by any fraudulent means or ways whatsoever, have raised or lowered the price of foodstuffs or goods or public papers and effects above or below the prices that would have been determined by natural and free competition in trade, shall be punished by imprisonment between one month and one year and a fine of five hundred to ten thousand francs.”

4 Mogul Steamship Co. v Mc Gregor, Cow \& Co, 23 QBD 588. contractual freedom and property rights were at stake. In this respect, the European practices were quite close to the us Classical Legal Thought prescriptions, which hindered the application of government interventions and antitrust rules enforcement in the Lochner era ${ }^{5}$.

By contrast, the inter-war period was characterised by the defence of the cartel as an efficient way of organising the economy and avoiding destructive competition. This position was defended by some of the major industry captains (G. Swope in the us for GE, A. Detoeuf in France for Alsthom) and ultimately by the public authorities (see the Laval decree-laws of 1935 in the French case, for instance).

The sole exception on the European continent was Germany with the Weimar Republic 1923 Competition Act. The most fundamental root of European competition law lies in assessing its failure to overcome the market power of large companies (Marty, 2015). Many legal scholars and economists who founded the Freiburg School (Freiburg im Breisgau) took part in the experience and concluded on the requirements for an effective competition policy. From this perspective, strong competition regulation is necessary to ensure the

5 A double phenomenon characterised the Lochner era. Firstly, it entailed an under-enforcement of antitrust rules based on protection of property rights and freedom of contract, this last one conceived as an approximation to individual liberty (Kirat \& Marty, 2019). Secondly, it involved the enforcement of these same rules against trade unions (see Glick, 2019a). Glick illustrates this enforcement bias through the case of the Second Cleveland Administration from 1893 to 1897 (the first one, from 1885 to 1889, was the first of the Democrat Party since the us Civil War). If the Cleveland Administration brought eight antitrust cases, four of them would target labour unions. The most striking case was Us v Debs in 1894. Debs' labour union boycotted Pullman railway cars in solidarity with striking workers at the Pullman Palace Car Co. He was sanctioned (and eventually jailed) as his position gave rise to an unlawful strike that interfered with mail delivery and interstate commerce (us Supreme Court, Debs In Re 158 us 564 (1895). 
competitive process itself against private economic powers. The government must not only act as a night watchdog, in the sense of $19^{\text {th }}$-century Manchesterian liberalism, but also as a government that actively intervenes to protect competition, including against itself, as soon as its natural result is the concentration of economic power (Mongouachon, 2011).

The Lippman Colloquium organised in Paris by Louis Rougier in 1938 was the focal point of this theoretical dynamic (Mirowski \& Plehwe, 2009). This conference marked the birth of neo-liberalism and was at the foundation of the Mont Pèlerin Society (MPS) after the war in 1947. Whether it was the Lippman Colloquium or the first conference of the MPs, the different branches of neo-liberalism were still present, namely the ordoliberals and what was to become, under the impetus of A. Director and E. Levi, the Second Chicago School (Bougette et al., 2015).

We will define the first approach, German ordoliberalism, in this subsection and the second, the Chicago School neoliberalism, in the following subsection. Ordoliberalism is based on a set of assumptions that are quite straightforward to define. First, two powers threaten the market process: governments, which may be tempted to instrumentalise (or neutralise) it, and private economic powers, which may be tempted to manipulate it for their benefit. Second, the market process is not seen as self-regulating. It can result in the concentration of economic power and thus in its exhaustion $^{6}$. Third, government intervention is required to counteract this tendency, but this intervention must be "neutral." It must therefore be based on quasi-constitutional rules and be impersonal so as not to be instrumentalised ${ }^{7}$. Fourth, the protection of competition through public interventions does

6 On the opposite, according to Friedman (1962), private monopolies raise fewer concerns than public ones as they are "generally unstable and of brief duration unless they can call government to their assistance” (p. 131)

7 The government may be captured by private economic power, as the best guarantee against competition are regulatory barriers to entry. See Zingales (2017) for an analysis of these phenomena. not aim to secure the actual outcome of competition (productive efficiency) but its process in itself and for itself.

The competitive process is conceived as a means of discovering and revealing the knowledge spread among the various players in the economy in the sense of Hayek (1945). Competition is also considered a tool for dispersing economic power. Competition is the mechanism for dispersing power in the market sphere, as democracy is the one for dispersing power in the political sphere (Marty \& Kirat, 2018). The two dimensions are consubstantially combined in the ordoliberal approach: the defence of democracy and the defence of competition go along with each other.

The above leads to two specificities. First, complete competition must be protected, which means a situation in which companies are price-takers, i.e., they do not have any market power ${ }^{8}$. Second, if an undertaking has such power, it must behave as if it did not. The notion of the dominant operator' special responsibility in the decisional practice of the European Commission stems from this approach ${ }^{9}$. The notion of special responsibility is defined as follows in the Eu jurisprudence:

A finding that an undertaking has a dominant position is not in itself a recrimination but simply means that, irrespective of the reasons for which it has such a dominant position, the undertaking concerned has a special responsibility not to allow its conduct to impair genuine undistorted competition on the common market ${ }^{10}$.

As we will see infra, it is more a matter of protecting the market process than securing allocative efficiency.

8 Such an approach considers that the best situation is the one of effective (and not a potential) rivalry on the markets preserving consumers' freedom of choice (see Amato, 1997).

9 EU Court of Justice, 9 November 1983, C-322/81, NV Nederlandesche Banden Industrie Michelin c. Commission and 13 February 1979, Case 85/76, Hoffmann-La Roche \& Co AG v Commission.

10 General Court (Court of First Instance), 30 September 2003, Case T-203/01 Manufacture française des pneumatiques Michelin v Commission. 
However, the European competition policy should not be regarded as mechanically driven by ordoliberalism. Firstly, the second German competition law was enacted in 1957, only after the Treaty of Rome. Secondly, other future Member States had their competition legislation before then. This was the case, for example, in France with the Commission Technique des Ententes created in 1953, which is a distant predecessor of our contemporaneous French Competition Authority. Thirdly, the Treaty of Rome, which resulted from the Messina Convention and the Spaak Report, was a compromise ${ }^{11}$ between national attitudes more oriented towards competition (Federal Republic of Germany) and others more inclined to use industrial policies (France and Italy). Fourthly, the rise of DG Competition, in which the ordoliberal influence was from the outset the strongest within the Commission (Vay, 2019), was only very gradual (Warlouzet, 2010). The implementation of Regulation 17/62 $2^{12}$ was challenging, and most of the ordoliberal influence came through the decisional practice of the Eu Court of Justice from the 1970s onwards. Its competition law-based judgments could be part of an integrationist process in the sense of Gerber (1998): the aim is to build a unified internal market governed by the rules of free and undistorted competition.

Before addressing the following points, it is worth noting that the internal competition laws of the various Eu Member States have adopted extensive objectives that go beyond the criterion of consumer welfare, which is never mentioned in the Treaty. Moreover, the competition laws of the various Member States are very composite in their structure. They encompass both restrictive practices law (competitor law) and antitrust law (market law). In doing so, the task of redressing the balance of economic power is never absent from competition law, as is the protection of the consumer and broader "non-economic" values (pluralism, among

11 See Warlouzet (2008) for an in-depth analysis.

12 EEC Council: Regulation No 17: First Regulation implementing Articles 85 and 86 of the Treaty, 21 February 1962. others). As Roda (2018) clearly shows, competition law is designed to reconcile the different objectives assigned to market competition, which are by nature conflicting.

\section{The issue of Bigness: Should the competition laws protect a given market structure?}

The purpose of the Eu decisional practice was to ensure a situation of effective competition. The aim was not to protect competitors, as it could be the case in a structuralist logic (à la Harvard), but to compel the dominant operator to check that its decisions will not have the effect (or are not likely to have the effect) of hindering competition on the relevant market. Therefore, the purpose is to protect competition not as regards its outcome but as regards its process.

This European perspective has conflicted in these two last decades with the approach developed by the second branch of neoliberalism, e.g., the Second Chicago School, since the 1950s. It is not a question, in this paper, of developing the genesis of the latter (see, for instance, Bougette et al., 2015) but of tracing some of its basic tenets.

First, this school is directly connected to the First School of Chicago, of which Henry Simons was the figurehead, yet it differs somewhat diametrically from his positions. Simons was a neo-liberal who endorsed the very same advocations as the ordoliberals. He was even more interventionist. He regarded the market as not self-regulating, as it was seen as inexorably converging towards the concentration of economic power. According to Simons, such a tendency was a problem in itself, whether from an economic or political perspective. It is, therefore, a requirement to implement the antitrust rules resolutely. This enforcement can dismantle firms to make competition possible again. According to Simons, dismantling may be a necessary antitrust remedy whatever its cost in terms of efficiency (Kirat \& Marty, 2019). The Second Chicago School will assume the perfect opposite of these positions. Situations of overwhelming dominance are no longer 
considered a problem, and the implementation of antitrust rules must be based on a single criterion: efficiency ${ }^{13}$, regardless of any considerations related to the competitive structure on the relevant market.

Second, the Second Chicago School refuses to consider certain practices as anticompetitive (except for horizontal price cartels, below-cost predatory strategies, naked exclusions). In other words, the approach prescribed as early as the initial studies in the late 1940s was to move away from per se rules to a rule of reason based on an assessment of the net effect of the practices in question ${ }^{14}$. Once again, the critical question was what the evaluation criterion should be.

The decisive contribution of Robert Bork (1966) was to propose a single criterion: the maximisation of consumer welfare ${ }^{15}$. Like Richard Posner's view, according to which wealth maximisation must be the sole criterion for decision making in economic analysis of law (Kronman, 1980), Robert Bork proposes the maximisation of consumer welfare as the

13 As Kovacic (2020, p. 482) states in his critical assessment of the academic literature devoted to the influence of the Second Chicago School on current us antitrust enforcement: "The modern US antitrust era is said to be a time when the Chicago School recast antitrust goals from an egalitarian perspective to a cramped concern with economic effects, especially prices paid by consumers."

14 For an historical perspective on the use of the rule of reason in Antitrust, see Hovenkamp (2018).

15 At this point, referring to Melamed and Petit (2018) we should emphasise that the Supreme Court's decision to adopt the consumer welfare test should not be considered literally. While it refers to a Consumer Welfare prescription (Reiter v Sonotone, 442 us 330, 1979), the Sherman Act and competition policies as a whole are not prescriptive but proscriptive in nature. It is a matter of sanctioning anti-competitive practices that are not conducive to the maximisation of welfare. To quote Melamed and Petit (2018), competition law prohibits practices that create or perpetuate market power on a basis other than economic efficiency. only criterion for competitive decision making ${ }^{16}$. This position is perfectly embodied by the Schor v Abbott Labs judgement of the $7^{\text {th }}$ Cir. in 2007: "If a manufacturer cannot make itself better off by injuring consumers through lower output and higher prices, there is no role for antitrust law to play." ${ }^{17}$

Nevertheless, Robert Bork's interpretation constituted a sharp departure from the Supreme Court's positions (Kirat \& Marty, 2019). In Trans-Missouri Freight (1897), the us Supreme Court had interpreted the Sherman Act as protection of small dealers and worthy men ${ }^{18}$. In its 1945 Alcoa ruling ${ }^{19}$, Judge Learned Hand had stated that antitrust law aims to "put an end to great aggregations of capital because of the hopelessness of the individual before them." Only four years before Robert Bork's article, the Supreme Court had reaffirmed in its Brown Shoe ruling ${ }^{20}$ that antitrust has to protect "small, locally owned businesses."

In our second part, we will revisit the discussion of this criterion both in terms of legitimacy and effects, but the consumer welfare standard is the cornerstone of what will become the more economic approach (or effects-based approach) in matters of competition rule enforcement.

The Supreme Court gradually adopted the approach advocated by the Second Chicago School in the second half of the 1970s with the GTE Sylvania $^{21}$ (rule of reason, e.g., balance of effects) and

16 The second Chicago School should not be seen as monolithic in terms of antitrust recommendations, either among its various promoters or over time. For example, Posner's prescriptions may deviate significantly from those of Bork in matters of predatory pricing (Kovacic, 2020).

17 Schor v Abbott Labs, 457 F.3d 608, 611, 7th Cir., 2007.

18 The United States v Trans-Missouri Freight Ass'n, 166 us 290 (1897).

19 The United States v Alcoa, 148 F.2d 416 (2d Cir. 1945).

20 Brown Shoe Co., Inc. v the United States, 370 us 294 (1962).

21 Continental Television v GTE Sylvania, 433 us 36 (1977) 
Sonotone (consumer welfare test ${ }^{22}$ ) judgments ${ }^{23}$. The appointment of William Baxter, by President Reagan, as head of the DoJ Antitrust Division (Assistant Attorney General), in the early 1980s consolidated this evolution ${ }^{24}$, which culminated in 2008 with the DoJ's report on Single Firm Practices. In this regard, the Economic Report of the President published in February 2020 by the Trump Administration largely revives this model, as shown in chapter 6, "Evaluating the Risk of Declining Competition," among other things (White House, 2020).

22 Note that the first mention of the consumer welfare test was made in 1975 in Justice Brennan's dissenting opinion on the National Bank Supreme Court decision (the United States v Citizens \& Southern Nat'l Bank, 422 us 86 (1975)): “Correspondent banking, like other intra-industry interaction among firms or their top management, provides an opportunity both for the kind of education and sharing of expertise that ultimately enhances consumer welfare and for "understandings" that inhibit, if not foreclose, the rivalry that antitrust laws seek to promote."

23 As Kovacic (2020) states, even if the Sylvania ruling cites Robert Bork's and Richard Posner's articles prominently, we should be cautious about the actual influence of academic literature on judges' decisions. See Hutchinson (2017) for an in-depth analysis of the use of economics by Supreme Court justices.

24 The 1982 DoJ merger control guidelines were a clear break from the 1968 guidelines. The aim was no longer "to preserve and promote market structures conducive to competition" but to prevent "harm to consumer welfare, generally in the form of price increases and output restrictions." We should notice that a more economic approach gradually spread throughout the us administration in the 1960 s around merger control, as Williamson (2002) stated. However, this influence was not a Chicagoan one. As it is also the case for Antitrust enforcement, the Harvard School has played a significant role in such a shift. Oliver Williamson was Special Economic Assistant to the Head of the Antitrust Division of the us Department of Justice in 1966-67, while Donald Turner was Assistant Attorney General for Antitrust (and the first PhD in economics to head the Antitrust Division).

\section{A very gradual implementation of the effects-based approach in the EU between 2005 and 2017}

This section presents the implementation of the more economic approach in enforcing $\mathrm{EU}$ competition law since 2005 to the detriment of the so-called forms-based one, e.g., the ordoliberal influenced one.

\section{The issue of Bigness: Should the competition laws protect a given market structure?}

The effects-based approach, in which consumer welfare was the only criterion to be used in antitrust matters, emerged latterly in the European Union compared to the Us. Several factors may explain the shift that was initiated in the early 2000s.

A first factor held to the search for soundness of the decisions in the face of the jurisdictional control exercised by the General Court (then the CFI, Court of First Instance). Indeed, the Court had annulled several Commission decisions (in the field of merger control ${ }^{25}$ ) because of a manifest error of assessment in the economic reasoning (Marty, 2007). These three cancellations have raised several legal certainty issues about the firms and credibility of the Commission (Roda, 2019). The use of an economic approach is intended to enhance legal certainty for the authority in charge of enforcing competition rules, the aim being to minimise the risk of the decision overturned or reversed on appeal ${ }^{26}$.

25 See for instance: CJE/02/50 6 June 2002, Judgment of the Court of First Instance in Case T-342/99, Airtours v Commission. In this judgment, the Court of First Instance annulled a previous Commission decision declaring the merger between Airtours and First Choice incompatible with the common market.

26 The Commission enjoys a certain margin of appreciation in complex economic assessments. The General Court has not entered the complexity of re-doing the economic analysis or revising the conclusions drawn therefrom by the Commission 
A second factor was related to the transatlantic debates at the beginning of the first decade of this century between US antitrust and EU competition policy. The Microsoft case gave rise to several debates induced by the (supposed or actual) EU consideration of competitors' interests in antitrust litigation. The motto "The purpose of antitrust laws is to protect competition, not competitors ${ }^{27}$ " was tantamount to blaming European competition policy for unduly favouring inefficient competitors to the detriment of consumers on the grounds of preserving an effective competition structure on the market, which is conceived as effective rivalry between firms (Fox, 2003). This tension reflects both a discussion on the objectives assigned to competition law and the trade-off between the criterion of maximisation of consumer welfare and the criterion of maximisation of total welfare, to which we shall return later. The effects-based approach was seen as the only way to enforce competition laws efficiently (Gerber, 2010).

Third, the focus on consumer welfare should not be separated from a broader movement towards public management whose accountability is

(oecd, 2019). However, the Court scrutinises complex (economic) evidence in considerable detail: "Referring to the existence of a margin of discretion does therefore not prevent the Court from carrying out a full and unrestricted review, in law and in fact."

27 See Brunswick Corp. v Pueblo Bowl-O-Mat, Inc., 429 us 477 (1977). Kovacic (2020, p. 479) insists on the importance of this statement in the current antitrust debate (see Khan, 2018a). "As amplified in later decisions, this phrase suggests that antitrust law is indifferent to the fate of individual firms unless their demise is linked to consumer detriment." Such an approach is not exclusively shared by the Chicago School; it was also (at least partially) endorsed by the Harvard School (see $\mathrm{Wu}, 2018)$. According to W. Kovacic, although the Harvard School has endorsed a broader range of legitimate aims for antitrust enforcement (unlike the Chicago-based approach), it never has adopted the "antitrust egalitarian approach" of the current new Brandeis movement. based on results. New public management assigns to public policies an efficiency objective to which competition policy makes no exception. The maximisation of consumer welfare is part of this objective of guiding and monitoring results. We will insist on our conclusion on the emphasis us (and European) public debate place on the requirements of predictability, administrability, and credibility in matters of competition law enforcement.

The implementation of this approach within the EU was gradual. Essential features were already contained in Regulations $1 / 2003^{28}$ and $139 / 2004^{29}$ (the latter on merger control) with distinct openings for an efficiency-based defence. However, the real turning point was the publication in 2005 of the report produced by the group of experts appointed by DG Competition (EAGCP, 2005). The latter was devoted to implementing a more economic approach to Article 82 of the Treat ${ }^{30}$, which deals with exclusionary or exploitative abuses (European Commission, 2009).

The report's advocates take up the criterion of consumer welfare maximisation by considering a derived criterion, the criterion of the efficient competitor. The Commission's February 2009 orientations on priorities regarding sanctioning abuses of dominant positions confirmed this inflexion ${ }^{31}$. The Commission insists on the importance that the implementation of the competition rules not result in undue protection of an economic operator whose productive efficiency would be lower than the one of the dominant firm (Marty, 2013).

28 Council Regulation (EC) No 1/2003 of 16 December 2002 on the implementation of the rules on competition laid down in Articles 81 and 82 of the Treaty.

29 Council Regulation (EC) No 139/2004 of 20 January 2004 on the control of concentrations between undertakings (the Ec Merger Regulation).

30 This article is now Article 102 under the numbering of the Lisbon Treaty, which entered into force in 2009.

31 Communication from the Commission, February 2009, Guidance on the Commission's enforcement priorities in applying Article 82 of the Ec Treaty to abusive exclusionary conduct by dominant undertakings. 
In other words, the aim is to prevent decisions that would transfer welfare between consumers and competitors. As Roda (2018) points out, this inflexion has in no way been based on legislative decisions; the EU Commission has made this change through its soft law texts.

This approach leads-at least in principle-to a greater emphasis on efficiency-based defence. It also amounts to departing from the formal prohibition of specific practices for dominant operators. The effects-based approach provides for a case-bycase assessment of the lawfulness of their market practices solely based on their net effect on consumer welfare.

The Commission's approach has, however, always been marked by a pragmatic stance. It has been a question not only of sanctioning practices that foreclose a competitor as efficiently as the dominant operator but also those likely to have that effect. In other words, there is no need for the competitor to be effectively crowded out from the market. The fact that foreclosure is not effective does not exonerate the dominant operator from its liability. Pragmatically, the test may be adjusted since small competitors cannot be reasonably expected to be as efficient as the dominant operator because of their economies of scale and scope. Thus, the reasonably equally efficient competitor test is used (Marty, 2013).

For instance, in margin squeeze cases where the vertically integrated dominant operator has a monopoly position in an upstream segment, the question is whether its downstream activity could be profitable if the same price conditions as those which the dominant operator imposed on its competitors operating in the same downstream market were applied to it. Nevertheless, the more economic approach implementation was not immediate and effective by far. Two criticisms have been made. The first concerned the actual place given to the efficiency-based defence. The second was the reluctance of Luxembourg courts, which are responsible for judicial review, to endorse this shift in their case law.

\section{The EU Court of Justice's jurisprudence: From defending conventional decisional practice to the Intel case turnaround in September 2017}

The Court of Justice has been often criticised for being too attached to its past decades' jurisprudence (Roda, 2018), which would have been an obstacle to a shift from formalism to effects on competition law enforcement (Petit, 2009). It would lead to sanctioning some of the strategies of dominant operators according to their form even without carrying out a balance of effects. The Intel judgment handed down in September $2017^{32}$ was interpreted as a substantial shift away from the positions successively taken by the Commission and the General Court ${ }^{33}$.

It is not a matter here of detailing the case, but the Intel case is of particular interest to us in that it has crystallised the European debate. In 2009, the Commission fined Intel $€ 1$ billion (then the highest fine for antitrust practices on the European continent) for a combination of foreclosure practices to the detriment of its competitor, AMD, in the microprocessors market. The wide range of sanctioned practices include retroactive loyalty rebates based on the share of each customer's consumption of chips sold by the dominant operator. The question was whether these rebates (which amounted to exclusivity rebates) were to be considered anticompetitive and therefore sanctioned in their form

32 Judgment of the Court (Grand Chamber) of 6 September 2017, Intel Corp. v European Commission, case $\mathrm{C}-413 / 14 \mathrm{P}$.

33 The 2012 Post Danmark judgment had already largely enshrined the primacy of the objective of efficiency over choice, quality, or innovation: "Competition on the merits may, by definition, lead to the departure from the market or the marginalisation of competitors that are less efficient and so less attractive to consumers from the point of view of, among other things, price, choice, quality or innovation” (\$22).Judgment of the Court of Justice (Grand Chamber), 27 March 2012, Post Danmark A/S v Konkurrencerådet, C-209/10. 
alone or whether an assessment of the effects had to be carried out to arrive at that conclusion.

In its 2009 decision, the Commission made this balance but only as a supplementary consideration, holding that the very form of the rebates put in place by Intel constituted an abuse of a dominant position. The EU General Court confirmed this appreciation in its $2014^{34}$ ruling. However, in September 2017, the Court of Justice returned the case to the Court of First Instance, considering that the latter was nevertheless required to review the balance of effects carried out by the Commission. This judgment is subject to divergent interpretations in Europeanist doctrine (Idot, 2018). For some scholars, it marks the Court's endorsement of the effects-based approach; for others, the Court's position is essentially procedural: The General Court is required to consider in its ruling the issues raised by the parties.

Whatever the interpretation of the Intel judgment, the Court of Justice has been gradually moving towards an effects-based approach through successive opinions of Advocates General, particularly in the context of referrals for preliminary rulings, which was, for example, the case for the AG Wahl's opinion in the Intel decision of September 2017 cited above. In his opinion ${ }^{35}$, he expressed a request for a preliminary ruling in a case of excessive pricing in the collective management of authors' rights in Latvia (2017). His position also corresponded to a consumer welfare focused $\operatorname{logic^{36}}$.

34 General Court, 12 June 2014, Intel Corporation v Commission, case T-286/09.

35 Opinion of advocate general Wahl, 6 April 2017, case C-177/16, Biedrība 'Autortiesību un komunicēšanās konsultāciju aǵentūra - Latvijas Autoru apvienība' v Konkurences padome (Request for a preliminary ruling from the Augstākā tiesa (Supreme Court, Latvia)).

36 "At any rate, I am not sure that concepts such as 'equitable' or 'appropriate' remuneration could be of great assistance to a competition authority. They seem to me as vague as the concepts of 'excessive’ or ‘unfair’ prices” (§78).
The same applies to the conclusions of AG Wathelet in the Orange Polska case related to the calculation of financial penalties ${ }^{37}$. The AG insisted that the amount of the fine must be based on the assessment of the actual damage. For the latter, the General Court should have "assessed whether the effects of the infringement had been correctly established by the Commission." To do so, the Court had to consider all the circumstances of the case in its assessment, particularly the defendant's evidence and arguments. In other words, abuse of a dominant position cannot be assessed in abstracto.

Still following the opinion of the AG Wahl ${ }^{38}$, the Court of Justice, in a judgment on a request for a preliminary ruling in the case of $\mathrm{MEO}^{39}$, also consolidated the effects-based approach by specifying that the implementation of tariff discrimination by a dominant operator cannot be regarded as anti-competitive in itself and that the-at least potential-anti-competitive effects had to be demonstrated. The mere existence of a difference in the treatment of trading partners is not enough to characterise abuse. Therefore, it is necessary "to carry out an examination of all the relevant circumstances to determine whether price discrimination produces or is likely to produce a competitive disadvantage."

Can we conclude that the effects-based approach is hegemonic in both $\mathrm{EU}$ and Us competition law enforcement? We will see in the second part that this finding can be subject to some nuances.

37 Opinion of Advocate General Wathelet delivered on 21 February 2018, Orange Polska SA v European Commission, case C-123/16P.

38 Opinion of Advocate General Wahl delivered on 20 December 2017, MEO - Serviços de Comunicações e Multimédia SA v Autoridade da Concorrência, case C-525/16.

39 CJEU, 19 April 2018, MEo - Serviços de Comunicações e Multimédia v Autoridade da Concorrência, aff. C-525/16 


\section{From the Capitol to the Tarpeian rock: The consumer welfare criterion challenged}

In this second part, the aim is to focus successively on the criticisms that may have been levelled against the consumer welfare criterion in the theoretical field and then in recent decision-making practice. However, it may be possible to challenge its alternatives on the merits.

\section{The consumer welfare test challenged both in the academic arena and in the digital economy}

The consideration of the consumer welfare criterion as the exclusive basis for enforcing competition rules is the subject matter of a twofold criticism, which relates to its legitimacy in the academic sphere and tractability in litigations related to the digital economy.

\section{Robert Bork's interpretation of the Sherman Act criticised: Fifty years of doctrinal controversies}

The first criticism of the consumer welfare criterion lies in its legitimacy considering the us antitrust legislative history. The concept of surplus was developed in economics by Marshall in his Principles of Economics published in 1890 at the very same time as the Sherman Act was enacted. Its promoters in the us Senate could not rely on such concepts. It was the economic power of big business that was targeted much more than its effects on prices. Such a reading is opposed to that of Bork (1966), for whom consumer welfare was the sole criterion underlying the legislator's reasoning. Despite this historical evidence, Robert Bork had maintained in his Antitrust Paradox published in 1978 that: "Congress designed the Sherman Act as a 'consumer welfare prescription." ${ }^{40}$

40 We will see that such a position, far from obvious in legal terms (see Melamed \& Petit, 2018), has been endorsed by the us Supreme Court in its 1979 Sonotone ruling.
Divergent positions were early articulated in the academic literature, which was the case of Lande (1982), for instance, for whom the Sherman Act was essentially aimed at unduly sanctioning welfare transfers linked to the exercise of economic power. Unlike Bork, Lande considers-in light of the legislative debates that preceded the enactment of the Sherman Act-that the legislators' objectives were less concerned with economic efficiency than with the protection of weaker parties in transactions with big companies, whether dependent companies, farmers, or consumers. It was not about protecting a given market structure or seeking an efficiency objective but about counterbalancing "abuses of dominance" in transactions.

Barak Orbach (2010) has pointed out the paradoxical nature of the consumer welfare test proposed by Bork, which can cover both the consumer surplus and the total surplus ${ }^{41}$. This ambiguity is a serious matter ${ }^{42}$. The overall surplus measures the net effect of a practice by balancing its effects on the consumer and the producer. A practice that significantly increases output (through productivity gains) but results in a slight loss of welfare for the consumer in terms of price could be validated against the first criterion and rejected against the second. In other words, the consumer welfare test encompasses issues of welfare distribution. From a Chicago-style perspective, the primary concern must be efficiency. The distributional dimensions of welfare must be considered ex post through other public policy tools ${ }^{43}$.

Moreover, the very notion of consumer welfare involves such trade-offs: some consumers may win, and others may lose. The net effect alone is taken into account. A Kaldor Hicks criterion is at

41 On this point, see also Blair and Sokol (2012).

42 According to Glick (2019b), "because the concept of [consumer welfare] is vacuous, it is not surprising that there is little agreement on its meaning or application in antitrust.”

43 Farrell and Katz (2006) present a clear statement of this view according to which a division of labour is preferable: "A number of reasons suggests that antitrust policy is poorly suited as redistribution vehicle in comparison with various tax and subsidy schemes.” 
stake and not a Pareto one ${ }^{44}$. Thus, welfare transfers are assumed. However, the test does not lead to balance efficiency gains realised by the producer and losses incurred by consumers, which is the core difference between a total welfare test and a consumer welfare one.

The ambiguity of Bork's analysis is decisive here. The total welfare test focuses only on efficiency, ignoring any consideration of the distribution of welfare. The consumer welfare test implies separating producer and consumer gains, which is as crucial in sanctioning anti-competitive practices as it is in merger control. As Wilson (2019) notes: "in merger analysis, the gains to the merging producers do not count; only the effect on consumer prices is relevant."

Beyond the criterion used to assess welfare, one of the most recent and sharpest criticisms of Robert Bork's approach was made by Lina Khan in her "Amazon's Antitrust Paradox" published in 2017 in the Yale Law Journal. Lina Khan's work is emblematic of the neo-structuralist movement, also named the new Brandeis movement ${ }^{45}$. According to Khan (2018b),

The Chicago focus on 'consumer welfare' [...] has warped American's antimonopoly regime, by leading both enforcers and courts to focus mainly on promoting 'efficiency,' on the theory that this will result in low prices for consumers. The fixation on efficiency, in turn, has largely blinded enforcers to many of the harms caused by undue market power including on workers, suppliers, innovators, and independent entrepreneurs-all harms that Congress intended for the antitrust laws to prevent. (p. 132)

Lastly, it should be noted that Bork's interpretation of this criterion prevents any sanction of undue transfers of welfare compared with a

44 However, these two criteria are challenged on their theoretical grounds by welfare economists (Glick, 2019b).

45 Former Woodrow Wilson's advisor from 1912 to 1916, Louis Brandeis, was appointed to the us Supreme Court in 1916. Figurehead of the associationalist movement (Berk, 2009), Brandeis was vehemently opposed to the then conventional view according to which bigness is a necessary evil to achieve efficiency because of scale economies. hypothetical situation of perfect competition (i.e., if the firms were price-takers) and does not protect the competitive process itself. Therefore, it departs significantly from the decisional practice of us antitrust until the 1970s and the ordoliberal foundations of European competition policy.

Consumer welfare may also be challenged on theoretical grounds. Firstly, it does not resolve situations where some consumers gain from certain practice and some others lose. Therefore, it assumes that individual utilities can be aggregated (Glick, 2018). Second, this criterion is based on a substantial rationality model that can be discussed in light of the contributions of behavioural economics (Stucke, 2007). However, it is vital to separate the effects-based approach, in general, from the exclusive focus on allocative efficiency, in particular. The first one is not specific to the Chicago School. As Kovacic (2020) underlines, the modern Harvard School also endorses such approaches. The Chicago School corresponds to the second one. Still, such an approach focuses on Robert Bork's views and is even more restrictive than those of other Chicagoan scholars. As Kovacic (2020, p. 485) states, "The Chicago School supplies an easily recognized villain, and Robert Bork is its sinister mastermind." Concisely, the two main challenged characteristics of this approach are i) its exclusive focus on allocative efficiency and ii) its ambiguity between consumer welfare and total welfare criteria.

\section{Is the consumer welfare criterion still suitable for our digital economy?}

The influence of the Second Chicago School was spotlighted in the Stigler Center report on digital platforms (Stigler Center for the Study of the Economy and of the State, 2019) mainly for blaming the noninterventionist bias of us antitrust enforcers. Even if the specificity of the Chicagoan prescriptions in this respect may be questionable, it remains that the report challenges the limits of the consumer welfare criterion in matters of competition law enforcement in the digital sector.

Competition damage-as well as consumers' damage-is not limited to a reduction of surpluses. 
For instance, how to capture the consequences of a reduction in the variety of goods and services available to consumers in the consumer welfare criterion? Or how to consider the effects of foreclosing even a less efficient competitor if it causes the disappearance from the market of a supplier whose products were distinct from the dominant firm's ones in terms of quality and privacy? In the area of mergers control, the acquisition of WhatsApp by Facebook is emblematic of this issue. The damage does not come from eliminating an offer or a higher price but from reducing privacy guarantees. Can the damage caused to consumers, in general, be estimated knowing that their preferences may direct them towards one or another product? Therefore, the disappearance of a supplier may damage competition, which this single aggregate criterion does not capture.

The activities of big firms in the digital economy today raise significant competition concerns. However, it is difficult to consider that they directly harm end-users or result in allocative inefficiencies. The business models of platforms are characterised by zero price models (or even negative prices in some cases when subsidies for specific equipment and services are included) and very high rates of innovation (Marty \& Warin, 2020). The consumer does not have to lose out-certainly in the short term and possibly, even in the long term - as long as market positions remain contestable, i.e., the competitive and technological turbulence makes the seemingly monopolistic positions of the moment precarious.

However, considering that the economic history of the last twenty years in the digital sector has no reason to repeat itself indefinitely, it is to be feared that competition will be significantly damaged. Even if today's dominant companies had once supplanted the past dominant firms (Yahoo!, MySpace), the technological and economic conditions have dramatically changed. Once it is assumed that barriers to market entry are inexorably increasing, today's monopolies may still be in place tomorrow.

In digital markets, barriers to entry may be due to the investments required, the accumulated data (and the controlled data flows), the algorithms developed, and the data processing capacities, but also the acquired position of a market gatekeeper or keystone player in an ecosystem (mobile operating system, digital industrial platform, cloud computing platform). What then are the competitive risks? The first one is the risk of predatory behaviour. The gains assured to consumers may only be short-term in nature. As soon as consumers are captive, i.e., locked in a silo, the platform may increase its prices or reduce innovation pace. There is, therefore, the potential for long-term damage through the development of silo effects. Consumers will be all the more dependent as they will have strong incentives to opt for single-homing, and their ability to exit the platform will be hindered by switching costs (whether in monetary terms or in loss of contents).

This dependency pattern does not only concern individual consumers. It can be extended to trading partners, i.e., the complementors of the digital ecosystem. The issue is twofold. It pertains to possible exclusionary abuses and exploitative ones. For the latter, it is no longer an issue of mark-up but an issue of mark-down. The keystone player may exploit its monopsony power to the detriment of their complementors. In such a context, the relevancy of the consumer welfare criterion may be challenged ${ }^{46}$.

Complementors may be in a position of economic and technological dependence (Smorto, 2018). These include independent vendors in marketplaces or application developers in mobile ecosystems. They are "attracted" to the platforms through contractual incentives or the provision of boundary resources (lines of code, data, interoperability protocols). However, these contractual

46 Yet this point is being debated. While a large body of academic literature highlights the difficulty of the effects-based approach in dealing with situations of monopsonist market power (in the platforms sector, on certain segments of the labour market, among others), these considerations have been taken into account in certain M\&A transactions in the us (in the context of the takeover of Essendant by Staples, for example). See Sycamore Partners II, L.P.; Staples, Inc; and Essendant Inc., FTC, file N¹81-0180, 28 January 2019. 
terms (such as data access) make them economically and technically dependent on the platform. The transactions between keystone players and their complementors are cooperative by nature but intrinsically unbalanced.

Damage to competition can be damage to a trading partner. From a French typology, it would be possible to consider that we are dealing here only with restrictive practices and not with anticompetitive practices. It would be a question of petit droit de la concurrence and not grand droit de la concurrence. The former deals only with contractual imbalance-related issues and not, as the latter does, with the effects on consumer welfare (e.g., effects on the whole market). The relationship between platforms and their complementors illustrates the issue of abuse of economic dependence (Bougette et al., 2019). Although this concept does not exist in Eu competition law, it can be found in French, Italian, German, Portuguese, Greek, and, since spring 2019, Belgian legislations ${ }^{47}$.

The European Regulation on Platform-toBusiness Relations adopted in June 2019 illustrates the seriousness of these issues. It shows that the dependency of complementors can induce a certain number of competitive damages that cannot be fully reflected in consumer welfare. These may include discriminatory access to a platform with critical infrastructure features (a platform in a gatekeeper position can be seen as an essential facility), which may involve unfair access not only in relation to competitors in a downstream or related market but also in transactional terms. Unfair conditions may be imposed on complementors. The issue is then not only fairness but also equal access to the market for companies (both complementors and competitors). Competition as a process may then be at stake.

On the one hand, competition is being damaged by restricting consumers' freedom of choice. On the other, harm to competition can take the form of harm to innovation. To the extent that access to

47 For an in-depth analysis of dominant digital platforms' capacity to abuse their economic power at the expense of their trading partners through unbalanced transaction terms, see Monnerie (2019). technological paths can be closed off by the platform, it can induce damage to dynamic efficiency, which was the sense of the damage to innovation put forward in the Microsoft case 16 years ago. In the same way, as soon as the platform "controls" the innovation dynamics of its complementors, it can reduce the incentives and capacities to develop disruptive innovations (which can disrupt the platform) to make only incremental innovations possible (Marty \& Warin, 2020). These are all the more useful for the keystone player in a digital ecosystem as they make it possible to perpetuate data flows and address the "non-consumption" issue.

In contrast, disruptive innovations are much less likely in this context, as the monopoly has no interest in replacing itself. Despite its investments, it would still benefit from the same rent. Therefore, the damage to innovation can damage the pace of innovation and composition (radical versus incremental). Given the market power that the platforms enjoy and their potentially irreversible nature, it is not a matter of departing from the criterion of consumer welfare but instead of adding specific considerations that are more directly related to the ordoliberal tradition.

Firstly, this may involve reinvigorating the concept of the dominant operator's special responsibility regarding the competition (Sauter, 2019). Because of its intrinsic strength (and the natural tipping tendencies of these markets), the dominant operator must ensure that its decisions do not bring about irreparable foreclosure of competitors who may not be able to compete on the merits. Secondly, some justification for imposing obligations might fall within the scope of asymmetrical regulation of competition, which could be the case of guaranteeing access to some of their assets on the ground of essential facility doctrine (or access to interface protocols) or the right to data portability. Such a special responsibility could also be expressed in terms of platforms' "technological" or "competitive" neutrality.

Therefore, it is not a question of addressing damage to consumer welfare but tackling potential harm to effective competition. By returning to the ordoliberal approach, it is the process of competition that must be preserved. From this perspective, 
the lawfulness of dominant firms' practices must no longer be assessed by their net effect on consumer welfare.

To some extent, although the us and European contexts are complicated to compare, the Neo-Brandeisian trend also endorses the logic of widening the spectrum of competitive harms that could be considered alongside the criterion of consumer welfare (Newman, 2019). However, the range of damages is considerably more comprehensive: decreased potential for the development of start-ups (the notion of killing zone), increased inequalities, privacy problems, growing fake news, among others. Therefore, it is more a matter of regulating the economic power of specific firms than a matter of defending competition. Ultimately, the standard effective competition proposed by Maurice Stucke and Marshall Steinbaum (2018) is closest to the approach defended within the EU. In the same vein, Wu's "protection of competition" test echoes the ordoliberal prescription according to which competition laws must protect the competition process itself and not its result: efficiency (Wu, 2018).

It is also necessary to stress the convergence of different simultaneous trends, which call into question, if not the criterion of the consumer's welfare itself, then at least its role as an exclusive consideration in enforcing the competition rules. We have already addressed these points above, but we propose to group them here in as a summary.

First, criticism of the consumer welfare criterion underlies a critique of the Chicago School. We have seen that it is far-reaching to associate the more economic approach with this single criterion, especially with this single school. Hovenkamp (2005) described the antitrust consensus in no way as a consensus around the Chicago School as it existed in the 1960s. The DNA of the American antitrust doctrine undoubtedly exhibits a double helix, and the courts do not base their decisions on textbooks from the 1960s (Kovacic, 2007). As Kovacic (2020) clearly states, the influence of the Chicago School on actual antitrust enforcement is often exaggerated in academic literature. The effects-based approach should not be reduced to Robert Bork's analysis, and the Chicago School had more play as a catalyst for the economic turn of the us antitrust enforcement than as a unique compass. The Harvard School had also initiated such a turn.

However, the adequacy between the criterion of consumer welfare, the effects-based approach, and Chicago-style prescriptions reflects two trends that have been very strong in recent decades. On the one hand, it is a question of taking one branch of economics-and one branch alone-and making it the alpha and omega of economic analysis. Many approaches, often complementary to the latter, are rejected outside the scope of the discussion. On the other, the Chicago approach has been less and less seen as an approach prescribing a case-by-case balance of effects but as increasingly per se rules by considering certain practices (especially vertical ones) as pro-efficient ${ }^{48}$. The outcome may be an under-enforcement of competition rules. The burden of proof lies exclusively on the complainants, and its standard is increasingly high. Such an approach is problematic since it is considered-contrary to Easterbrook (1984) - that a false negative decision can be more costly than a false positive one.

Secondly, digital economy evolutions question the reasoning that focuses on allocative efficiency alone, statically, and based on partial equilibrium. Three consequences are to be taken into account.

48 For a striking illustration of such tendencies, see the draft published by the ftc and the DoJ regarding the Vertical Merger Guidelines (DoJ-FTC, 2020, p. 9): "Because vertical mergers combine complementary economic functions and eliminate contracting frictions, they have the potential to create cognizable efficiencies that benefit competition and consumers. Vertical mergers bring together assets used at different levels in the supply chain to make a final product. A single firm able to coordinate how these assets are used may be able to streamline production, inventory management, or distribution, or create innovative products in ways that would have been hard to achieve through arm's length contracts.” Economides et al. (2020, p. 7) also insist on the adverse permissive effects the implementation of this draft might produce through its "misplaced emphasis on the elimination of double marginalization as an efficiency justification for vertical mergers.” 
First, competition turbulences in digital markets may not be as severe as fifteen years ago (Marty \& Warin, 2020). As noted above, the growing importance of barriers to entry means that the contestability of markets is less and less assured. Second, platform markets are characterised by additional difficulties in delineating relevant markets and assessing the effects on all business sides, which does not invalidate the consumer welfare criterion, but requires recognition of the increasing risks of false negatives. Third, the development of these digital markets itself legitimately increases the scope of competitive concerns. Much of the debate around hipster antitrust focuses on the necessity to consider non-economic or at least very general dimensions (employment, inequalities) in competition authorities' decisions.

Although the parallel is not necessarily relevant, it could be argued that each public policy tool must have a specific objective and that bringing antitrust to address macroeconomic objectives may at best have sub-optimal results. This "Tinbergen rule" should not mean that the competition judge considers broader dimensions, but it does mean, as we will see in our last subsection, that he should then balance conflicting objectives for which it is difficult to find common equivalents. For instance, how could a competition judge arbitrate between the interests of consumers and the interests of employees?

However, this enlargement can also take place within the competition policy itself. The development of the platform economy integrates into the competitive reasoning concerns that fall under other branches of law. This is the case of consumer law since the users of the platforms are private individuals, which is also the case of contract law. Platforms involve numerous vertical contractual restrictions, which concern restrictive practices (le petit droit de la concurrence) and competition law enforcement (le grand droit de la concurrence). Contractual imbalances raise concerns not only for the parties concerned but also for competition. They may give rise to exclusionary abuses, exploitative abuses, and abuses of economic dependence that competition law must (and can) address (Bougette et al., 2019).
Such concerns echo the reflections, particularly in the context of merger control, about the notion of trading partner welfare. Contractors dependent on platforms are not protected any more than competitors in the past, but barriers to accessing the market may harm the consumer regarding freedom of choice and the diversity of options available. Similarly, if exploitative abuses are committed, trading partners can no longer invest, thus benefiting consumers. Furthermore, if the keystone player controls the technological trajectory of its complementors, it can hinder any disruptive innovation and lock its complementors into innovations that reinforce their (and consumers') dependence on it.

The last area of law at stake is the right to protection of personal life (privacy). The platforms involve constant trade-offs between the transfer of personal data and the provision of services. A free service can be paid for by a disproportionate extraction of personal data. The consumer may not be aware of this (the so-called privacy myopia). Simultaneously, such extraction may offer a data advantage to the dominant player against its (potential) competitors. It may create a barrier to entry. The long-term effects of this asymmetric data extraction can reduce the market's contestability and eventually its foreclosure, which constitutes a particular form of predation for which we must develop tools to balance the two effects. The case of Facebook's takeover of WhatsApp is a good illustration of these trade-offs between efficiency and privacy. In addition, it made it possible to "deconstruct" the notion of consumer by opposing consumers who did not value the protection of personal data (and who could therefore use Facebook Messenger) and those who agreed to pay the price to access the service in exchange for the protection of their data.

\section{The worst criterion except for all the others?}

Newman (2019), commenting on Hovenkamp's 2005 book The Antitrust Enterprise, indicated that antitrust seemed to have reached the equivalent of the end of history with the effects-based approach 
until a decade ago. Within this perspective, the origin and termination of all analyses lay in measuring prices and output ${ }^{49}$. In other words, allocative efficiency is how practices are evaluated and their sole criterion of assessment.

While this criterion has apparent limitations, it has advantages. It provides a single standard against which practices can be measured and achieves the objectives of legal certainty. The latter relates to the clarity of the rule, the limited application of discretionary aspects, and finally, the predictability of its enforcement. Finally, adopting a single criterion makes it possible to avoid arbitration between qualitative and often conflicting objectives. The analysis developed by Melamed and Petit (2018) as a (reasoned) defence of the consumer welfare criterion goes in this direction. Consumer welfare provides a legitimate criterion insofar as it does not carry underlying values or political choices ${ }^{50}$.

Similarly, from public choice, a one-dimensional criterion is more difficult for interest groups to manipulate (Dorsey et al., 2018). The application of the test is predictable, which enhances the legal security of operators and limits the risk of opportunistic lawsuits that are particularly costly for defendants ${ }^{51}$.

49 Focusing on prices and outputs alone removes any quality dimension and can lead to false negatives in platform markets operating under zero-price models. Nevertheless, more sophisticated versions of the consumer welfare criterion incorporate dimensions such as quality or diversity of supply. These non-monetary variables are converted into prices as part of the analysis. For instance, such an approach has been implemented in the airline industry (see Keating et al., 2013).

50 This position can nevertheless be discussed in light of the debates to which it gives rise. The choice of a given economic method or tool cannot be regarded as neutral or purely technical. To this end, one should think of the debates in the us between technical antitrust and political antitrust. While it is already difficult to consider competition law to be neutral, its implementation invariably involves choice and political priorities.

51 This point can also be discussed concerning the inner efficiency of antitrust procedures. The
We present above some criteria proposed in the academic literature. Do they constitute alternative or complementary standards to consumer welfare? It seems that the second option should be dismissed because of its imperfections. It nevertheless captures essential dimensions that the former cannot.

A first criterion could be the consumer freedom of choice standard. Any "conduct that artificially limits the natural range of choices in the marketplace" (Lande, 2001, p. 504) would be anti-competitive. A second criterion can consist of renewing-with the original 1890 legislative intent-and searching for conciliation for multiple purposes, such as preserving a dispersed industry structure or fairness in economic transactions (Wilson, 2019). However, it raises the difficulty in arbitrating among these objectives ${ }^{52}$. A third criterion can be the protection of the competitive process. Competition policy should sanction all practices that can impair the latter (Werden, 2014).

This brief overview shows that the consumer welfare criterion criticisms are more likely to call for an adjustment of the criterion than for its possible abandonment. When it comes to the abuse of a dominant position, it is, in any case, a question of assessing a potential effect on competition. An effects-based approach is necessary; the consumer

more economic (i.e., effects-based) approach involves collecting and processing considerable volumes of data by defendants. Simpler-i.e., more formal-rules could limit these costs. Let us add a dimension: the data required are mainly price and sales data of the incriminated dominant undertaking. They often do not allow an assessment of the impact of the practices on consumer welfare. Here we come to a paradox already pointed out by Bosco (2013): the more economic approach is mainly reflected in an analysis of dominant operators' costs in predatory pricing cases rather than in any measure of consumer welfare.

52 us political and theoretical debates tend to add additional goals to these objectives such as income inequality reductions or job protection. The second issue is related to the monopsonist power (or oligopsonist one) in specific job market segments such as the high-tech one. The first one was raised, among others, by Khan and Vaheesan (2017). 
surplus criterion is constantly called upon to play a central role, if only because of its tractability ${ }^{53}$. Nonetheless, it should not be an exclusive and overly restrictive test in its operationalisation by unreasonably raising the standard of proof and placing it on the complainant $s^{54}$. Therefore, the risk is being exposed to false negatives and tipping towards pro-trust antitrust that constitutes both economic and political risks (Marty \& Kirat, 2018).

Let us recall one of the lessons of original neo-liberalism: the concentration of economic power-if no longer reversible-involves two risks for democracy. The first is the risk of political power capture by private economic powers (we could add to this) when platforms play a central role in access to information, the risk of manipulating public opinion, whether voluntary or not ${ }^{55}$ ). The second risk is that the concentration of economic power will trigger a backlash from the political power in terms of regulation, which should not come as a surprise: this was already the case in 1912 in the us with the presidential debates between Taft, Roosevelt, and Wilson (see Crane, 2015). The concentration of economic power posits the political question of the modalities of regulation between Jeffersonian and Hamiltonian approaches (Pasquale, 2018). The

53 Wilson (2019) insists on three favourable characteristics associated with the consumer welfare criterion: predictability, administrability, and credibility.

54 Crémer et al. (2019, p. 4) propose for digital markets to "impose on the incumbent the burden of proof for showing the pro-competitiveness of its conduct."

55 The question is beyond the scope of this reflection, but the accumulation of personal data combined with the isolation of consumers in vertical silos raises serious concerns about the social control of individuals. As such, the strategies-economically rational and efficient-of the Internet's big firms can be questioned from the angle of political desirability (Pasquale, 2013). In this artificial intelligence era, do we wish to endow the powerswhether private or public-with such tools of social control, even if they bring unquestionable efficiency gains (Pasquale, 2018)? characteristic of the 1930s neoliberal approach was to lean towards the former.

Similarly, the contestation of the consumer welfare test- or the restrictive use made of itshould not call for implementing a discretionary antitrust that could lead either to a neo-classical legal thought (reactionary antitrust) or to a return to an obsolete and impractical structuralist model. An antitrust that would target the Bigness itself, which would champion dismantling in the absence of demonstration of damage to the consumer, would cause several damages. First, concentration as such occurs naturally for the sectors of activity concerned. Second, it does not in itself pose a problem as long as competitors and consumers can exert countervailing pressure. Third, eventual dismantling-if practicable-would impose social costs that are difficult to anticipate and could result in significant losses of efficiency, which does not mean that structural remedies should be excluded per se, but that they should be subjected to a cost-benefit analysis, of which consumer welfare is an essential dimension.

Nevertheless, many considerations taken into accoun in the context of Us antitrust make sense in the European context as soon as they are acclimatised to it. The standard of effective competition proposed by Steinbaum and Stucke (2018) or that of the defence of the competition process supported by $\mathrm{Wu}$ (2018) are not far from the ordoliberal logic. For instance, Tim Wu (2018) suggests that practices should be weighed against their compatibility with competition on the merits. A strategy that has the effect of hindering or distorting the competitive process would then be considered anti-competitive. These dimensions echo the case-law concept established by the Court of Justice of the dominant operator's special responsibility. The implementation of this approach had been made narrower by the so-called more economic approach (of which the criterion of consumer welfare was the keystone).

These current developments in both the competitive, political, and theoretical fields suggest that the European Commission builds the model that may constitute an attractive compromise. Without disavowing the benefits of the 
effects-based approach, the latter maintains an ordoliberal conception of competition (a process to be protected for itself and possibly against itself). The eu Court of Justice and the Eu Commission increasingly consider dimensions that had been progressively marginalised, such as transparency, fairness, or loyalty (Petit, 2018), and retain a plurality of objectives among which efficiency is an essential but not exclusive component. These objectives are straightforward: the protection of free, undistorted competition on the merits. The criterion of consumer welfare makes it possible to reflect-at least partially-the last objective but needs to be supplemented by further analysis for the first two. Competition need not be reduced to its result-e.g., allocative efficiency-. It is a tool of discovery in the Hayekian sense of the term, an instrument of discovery of knowledge in society, and finally-and this point is essential-a vector of dispersion of economic and political power. There can be no efficiency without free competition and no democracy without free competition.

\section{Discussion}

As a discussion, we might consider two issues. The first one deals with the potential effects of implementing a "protection of competition" criterion. The second one is related to a quite surprising defence of a total welfare criterion, presented by Wilson (2019), as an alternative for antitrust enforcement.

If the criterion of consumer welfare is likely to remain the cornerstone of the implementation of competition rules, it appears that it cannot be the only criterion, as it does not capture all the damage to competition. Is the concept of damage to competition a good alternative? The notion of the dominant operator's special responsibility can be an interesting compromise, more satisfying than truly hipster style approaches as a return to nonfaulty monopolist rules and eventually advocacy for structural remedies such as dominant platform dismantling ${ }^{56}$ or "antitrust lawsuits to unwind previously completed mergers" involving tech giants

56 See Khan (2019) in the case of e-commerce platforms.
(Kovacic, 2020, p. 487). However, how should it be implemented in practice? It implies specific duties for dominant operators, such as mandatory access to data or platforms (Chaiehloudj, 2020).

On the one hand, it remains essential to avoid excessively asymmetrical competition regulation models and, on the other hand, to guarantee non-discriminatory practices regarding access to or carrying obligations for third party offers or contents. Melamed and Petit (2019) exemplify the scope of these obligations: "the promotion of inter and intra platforms rivalry would require the imposition of positive obligations - must carry requirements, mandatory API sharing, data portability measures-on platform-based firms [...]" (p. 765). It should be noted that this raises another essential legal issue: Should competition law merely sanction certain practices, or should it impose market behaviour? In other words, how can such an essential facility doctrine be managed effectively?

Surprisingly, the consumer welfare criterion is also challenged by the total welfare one. We have noted that Robert Bork's conception was ambiguous. His consumer welfare may be conceived as total welfare. According to Hovenkamp (2019):

Bork did not use the term 'consumer welfare' in the same way that most people use it today. For Bork, 'consumer welfare' referred to the sum of the welfare, or surplus, enjoyed by both consumers and producers. Bork referred to consumer welfare as 'merely another term for the wealth of the nation.' (p. 101)

Wilson (2019) considers this total welfare criterion can be relevant as soon as we assign to competition laws the sole purpose of promoting economic efficiency. Such a focus on total surplus makes sense from a Chicagoan perspective. As soon as competition law must cope with efficiency, it is out of the scope to consider welfare distribution, as the consumer welfare criterion imposes to do so. It is only a matter of expanding the size of the pie (see, for instance, Williamson, 1968).

The Second Chicago School rejects distributional considerations outside the scope of economics. The reduction of welfare inequalities pertains 
to the sphere of political preferences; it should be addressed through taxation ${ }^{57}$. In the same vein, the increasing concentration of market power has both a potential impact on efficiency (by deterring potential competitors from investing and from innovating) but also on the robustness of democracy (the higher the financial risks associated with adverse political choices, the higher the capacity and the incentives to invest for exerting an influence on political power). The regulation of lobbying activities or the reform of campaign financing can address the capacity to convert economic power in a political one (Shapiro, 2018) but not the private interests to capture public regulation.

According to Wilson (2019), adopting this criterion could lead to more favourable decisions if, for example, a merger would bring significant efficiency gains ${ }^{58}$ in industries characterised by high levels of fixed $\operatorname{costs}^{59}$. Among the arguments presented in defence of a total welfare criterion is the possibility of considering multi-market effects. A transaction may increase the market power on one segment and have positive effects on another. Such an operation may also transfer innovations from one segment to another and, by doing so, may generate dynamic efficiencies.

It, therefore, appears that the debate over the criteria that should guide the competitive decision requires a re-examination of the criterion of consumer welfare, as it stems from Robert Bork's work. Two avenues of evolution are therefore to be considered. As Christine Wilson (2019) does, the first is to question the relative interest in considering the total welfare test, which is, after all, very close to the consumer welfare test as defined by Bork. The second is to revive the European

57 However, Piketty (2013) has demonstrated that income and capital inequalities significantly impact potential economic growth.

58 Christine Wilson (2019) also quotes the case of the 1986 Canadian Competition Act that opens the door to considering a broader perimeter of efficiency gains in mergers (sec. 96(1)).

59 However, while such a transaction generates efficiency gains, it also increases market power and thus reduces the incentives to make consumers benefit from these gains (Rainelli, 2006). tradition based on ordoliberalism, from which the EU has only recently begun to depart. Moreover, by combining an effects-based approach and considering the dominant operator's special responsibility for maintaining effective competition, this approach makes it possible to reconcile different competition policy objectives without giving way to a structuralist approach. It is always a question of balancing several values ${ }^{60}$, which inexorably gives room for discretion.

However, two arguments must be taken into consideration. First, the criterion of consumer welfare also involves such trade-offs, even if only between different consumers. Second, an ordoliberal approach seems exceptionally reasonable in an economy where the digital sector is increasingly important. It is characterised by three features that argue in favour of this approach: the increasing and perhaps irreversible market concentration, the need to ensure the sustainability of the innovation-based competition model, and coping with the unpredictability of market dynamics. From this perspective, the criterion of protecting the competitive process makes more sense than ever (de Streel, 2020).

\section{Acknowledgement}

The author would like to thank the Universidad Militar Nueva Granada for its invitation to the VII Congreso Internacional de Derecho Privado held in Bogotá in November 2019. He is particularly grateful to Claudia Margarita Martinez, Fulvio Germán Santarelli, Carlos Andrés Perilla, Juan Carlos Villalba Cuéllar, and Javier Francisco Franco Mongua for the constructive and stimulating exchanges at this conference.

\section{References}

Amato, G. (1997). Antitrust and the bounds of power - the dilemma of liberal democracy in the history of the market. Hart Publishing.

60 As Roda (2018) demonstrates, the EU Competition law enforcement is characterised by a search for pluralism contrasting with an exclusively efficiency-oriented approach. 
Berk, G. (2009). Louis D. Brandeis and the Making of Regulated Competition, 1900-1932. Cambridge University Press.

Blair, R. D. \& Sokol, D. D. (2012). The Rule of Reason and the Goals of Antitrust. Antitrust Law Journal: An Economic Approach, 78(2), 471-504. https://doi. org/10.2139/ssrn.2039337

Bork, R. H. (1966). Legislative Intent and the Policy of the Sherman Act. Journal of Law and Economics, 9, 7-48. https://doi.org/10.1086/466617

Bork, R. H. (1978). The Antitrust Paradox - A Policy at War with Itself. The Free Press.

Bosco, D. (2013). Le test de l'opérateur aussi efficace : une nouvelle ère ? Concurrences, (3), 12-15.

Bougette, P., Budzinski, O., \& Marty F. (2019). Exploitative Abuse and Abuse of Economic Dependence: What Can We Learn from an Industrial Organization Approach? Revue d'Economie Politique, 129(2), 261-286. https:// doi.org/10.3917/redp.292.0261

Bougette, P., Deschamps, M., \& Marty, F. (2015). When Economics met Antitrust: The Second Chicago School and the Economization of Antitrust Law. Enterprise and Society, 16(2), 313-353. https://doi.org/10.2139/ ssrn. 2470429

Chaiehloudj, W. (2020). Quels outils efficaces pour les autorités de concurrence dans l'économie numérique? Contrats, Concurrence, Consommation, (3), 4.

Crane, D. A. (2015). All I Really Need to Know About Antitrust I Learned in 1912. Iowa Law Review, 100(5), 2025-2038.

Crémer, J., de Montjoye, Y.-A., \& Schweitzer, H. (2019, April). Competition Policy for the Digital Era. DG Competition.

de Streel, A. (2020). Should digital antitrust be ordoliberal? Concurrences, (1), 2-4.

Didry, C. \& Marty, F. (2016). La politique de concurrence comme levier de la politique industrielle dans la France de l'après-guerre. Gouvernement et Action Publique, 5(4), 23-45. https://doi.org/10.3917/gap.164.0023

Dorsey, E., Rybnicek, J., \& Wright J. D. (2018, April). Hipster Antitrust Meets Public Choice Economics: The Consumer Welfare Standard, Rule of Law, and Rent-Seeking. Competition Policy International Antitrust Chronicle.

EAgCP. (2005, July). An Economic Approach to Article 82.

Easterbrook, F. H. (1984). The Limits of Antitrust. Texas Law Review, 63(1), 1-40.

Economides N., Kwoka J., Philippon T., Singer H., \& White L.J. (2020). Comments on the DOJ/FTC Draft Vertical Merger Guidelines. NET Institute, Working Paper 20-04.
European Commission. (2009, February 24). Guidance on the Commission's enforcement priorities in applying Article 82 of the EC Treaty to abusive exclusionary conduct by dominant undertakings, [communication]. 2009/C45/02. https://eur-lex.europa.eu/LexUriServ/ LexUriServ.do?uri=OJ:C:2009:045:0007:0020:EN:PDF

Farrell, J. \& Katz, M. L. (2006). The Economics of Welfare Standard. Competition Policy International, 2(2).

Fox, E. M. (2003). We Protect Competition, You Protect Competitors. World Competition, 26(2), 149-165.

Friedman, M. (1962). Capitalism and Freedom. University of Chicago Press.

Gerber, D. (1998). Law and Competition in the Twentieth Century: Protecting Prometheus. Clarendon Press.

Gerber, D. (2010). Global Competition - Law, Markets and Globalization, Oxford University Press.

Glick, M. (2018). The Unsound Theory Behind the Consumer (and Total) Welfare Goal in Antitrust. Antitrust Bulletin, 63(4), 455-493. https://doi.org/10.2139/ ssrn.3308882

Glick, M. (2019a). Antitrust and Economic History: The Historic Failure of the Chicago School of Antitrust. https://ssrn.com/abstract=3378809

Glick, M. (2019b). American Gothic: How Chicago Economics Distorts 'Consumer Welfare' in Antitrust. Working Paper Institute for New Thinking, (99), 1-35. https://doi.org/10.36687/inetwp99

Hayek, F. (1945). The Use of Knowledge in Society. American Economic Review, 35(4), 519-530.

Hildebrand, D. (2012). The Emergence of the European School," Concurrences, 2, 4.

Hovenkamp, H. J. (2005). The Antitrust Enterprise: Principles and Execution. Harvard University Press.

Hovenkamp, H. J. (2018). The Rule of Reason. Florida Law Review. 70, 80-167.

Hovenkamp, H. J. (2019). Is Antitrust's Consumer Welfare Principle Imperiled? [working paper]. University of Pennsylvania Carey Law School University.

Hutchinson, C. (2017). Law and Economics Scholarship and Supreme Court Jurisprudence, 1950-2010," Lewis and Clark Law Review, 21(1), 145-209.

Keating, B., Israel, M. A., Rubinfeld, D. L., \& Willig, R. D. (2013). Airline Network Effects and Consumer Welfare. Review of Network Economics, 12(1), 1-36. https:// doi.org/10.1515/rne-2013-0110

Kirat, T. \& Marty, F. (2019). The Late Emerging Consensus among American Economists on Antitrust Laws in the Second New Deal," Cahier Scientifique du CIRANO, 12 . 
Khan, L. M. (2017). Amazon's Antitrust Paradox. Yale Law Journal, 126, 710-805.

Khan, L. M. (2018a). The Ideological Roots of America's Market Power Problem," Yale Law Journal. 127, 960.

Khan, L. M. (2018b). The New Brandeis Movement: America Antimonopoly Debate," Journal of European Competition Law, 9(3), 131-132. https://doi.org/10.1093/ jeclap/lpy020

Khan, L. M. (2019). The Separation of Platforms and Commerce. Columbia Law Review, 119(4), 973-1098.

Khan, L. M. \& Vaheesan, S. (2017). Market Power and Inequality: The Antitrust Counterrevolution and Its Discontents. Harvard Law \& Policy Review, 11, 235-294.

Kovacic, W. E. (2007). The Intellectual DNA of Modern Us Competition Law for Dominant Firm Conduct: The Chicago/Harvard Double Helix. Columbia Business Law Review, 1(1), 1-80.

Kovacic, W. E. (2020). The Chicago Obsession in the Interpretation of us Antitrust History. University of Chicago Law Review, 87(2), 459-494.

Kronman, A. T. (1980). Wealth Maximization as a Normative Principle. Journal of Legal Studies, 9(2), 227-242. https://doi.org/10.1086/467637

Idot, L. (2018). Intel: the long awaited ECJ Ruling. Concurrences, 1 .

Joliet, R. (1967). The Rule of Reason in Antitrust Law American, German and Common Market Laws in Comparative Perspective, Springer.

Lande, R. H. (1982). Wealth Transfer as the Original and Primary Concern of Antitrust: The Efficiency Hypothesis Challenged. Hastings Law Journal, 34(1), 65-151. http://dx.doi.org/10.2139/ssrn.2065413

Lande, R. H. (2001). Consumer Choice as the Ultimate Goal of Antitrust. University of Pittsburgh Law Review, 62(3), 503-525. https://doi.org/10.2139/ssrn.1478680

Marty, F. (2007). Le contrôle des concentrations en Europe et aux Etats-Unis : Critères économiques et sécurité juridique. La Revue de l'ofCE, 100(1), 85-120. https://doi. org/10.3917/reof.100.0085

Marty, F. (2013). Critère du concurrent aussi efficace et approche par les effets en matière d'éviction par les prix. Concurrences, (3), 20-23.

Marty, F. (2015). Towards an Economics of ConventionBased Approach of the European Competition Policy. Historical Social Research, 40(1), 94-111.

Marty, F. \& Kirat, T. (2018). Les mutations du néolibéralisme américain quant à l'articulation des libertés économiques et de la démocratie. Revue Internationale de Droit Economique, XXXII(4), 471-498. https:/doi. org/10.3917/ride.324.0471

Marty, F. \& Warin, T. (2020). Innovation in Digital Ecosystems: Challenges and Questions for Competition Policy. Cahier Scientifique du CIRANO, (10).

Melamed, D. \& Petit, N. (2019). The Misguided Assault on the Consumer Welfare Standard in the Age of Platform Markets. Review of Industrial Organization, 54(4), 741774. https://doi.org/10.1007/s11151-019-09688-4

Mirowski, P. \& Plehwe, D. (2009). The Road from Mont Pèlerin. Harvard University Press.

Monnerie, N. (2019). L’abus de domination sur le marché numérique : pour une lecture juridique du déséquilibre économique à l'aune des oligopoles. Concurrences, (3), 67-75.

Mongouachon, C. (2011). L'ordolibéralisme : contexte historique et contenu dogmatique. Concurrences, (4), 70-78.

Newman, J. (2019). Reactionary Antitrust. Concurrences, (4), 66-72.

OECD. (2019). The standard of review by courts in competition cases-Note by the EU. Standard of review by courts in competition case.

Orbach, B. (2010). The Antitrust Consumer Welfare Paradox. Journal of Competition Law and Economics, 17(1), 133-164.

Pasquale, F. (2013). Privacy, Antitrust, and Power. George Mason Law Review, 20(4), 1009-1024.

Pasquale, F. (2018). Tech Platforms and the Knowledge Problem. American Affairs, (summer), 3-16.

Petit, N. (2009). From formalism to effects? The Commission's Communication on enforcement priorities in applying article 82 EC. World Competition, 32(4), 485504. https://doi.org/10.2139/ssrn.1476082

Petit, N. (2018). Droit européen de la concurrence (2 $2^{\text {nd }}$ edition). LGDJ.

Piketty, T. (2013). Le Capital au XXI ${ }^{\mathrm{e}}$ siècle. Le Seuil.

Rainelli, M. (2006), « À propos du règlement européen $n^{\circ} 139 / 2004$ relatif au contrôle des concentrations entre entreprises : une vision sceptique de la prise en compte des gains d'efficacité," Revue Internationale de Droit Economique, 2006-1, pp. 45-54.

Roda, J.-C. (2018). Réflexion sur les objectifs du droit français de la concurrence, Recueil Dalloz, 1504.

Roda, J.-C. (2019). Droit de la concurrence. Mémento Dalloz.

Sauter, W. (2019) A duty of care to prevent online exploitation of consumers? Digital dominance and special responsibility in EU competition law. Journal of Antitrust Enforcement, 8(2), 406-427. https://doi.org/10.1093/ jaenfo/jnz023 
Shapiro, C. (2018). Antitrust in a time of populism. International Journal of Industrial Organization, 61, 714748. https://doi.org/10.1016/j.ijindorg.2018.01.001

Smorto, G. (2018). Protecting the weaker parties in the platform economy. In N. Davidson, M. Finck, \& J. Infranca (Eds.), Cambridge Handbook on Law and Regulation of the Sharing Economy (pp. 431-446). Cambridge University Press.

Steinbaum, M. \& Stucke, M. E. (2018). The Effective Competition Standard: A New Standard for Antitrust. WP Roosevelt Institute.

Stigler Center for the Study of the Economy and of the State. (2019, May). Report of the Committee for the Study of Digital Platforms: Market Structure and Economic Performance.

Stucke, M. E. (2007). Behavioral Economics at the Gate: Antitrust in the $21^{\text {st }}$ Century. Loyola University Chicago Law Journal, 38(3), 513-591.

us Department of Justice and Federal Trade Commission. (2020, January). Draft Vertical Merger Guidelines. https://www.justice.gov/opa/pr/doj-and-ftc-announce-draft-vertical-merger-guidelines-public-comment

Vay, M. (2019). L'impossible doctrine européenne du service public : aux origines du service d'intérêt économique général (1958-1968). Revue Française de Sciences Politiques, 69(11), 75-94. https://doi.org/10.3917/ rfsp.691.0075

Warlouzet, L. (2008). "Europe de la concurrence et politique industrielle communautaire. La naissance d'une opposition au sein de la CEE dans les années soixante. Histoire, Economie et Société, 27(1), p. 47-61. https://doi.org/10.3917/hes.081.0047
Warlouzet, L. (2010). The Rise of the European Competition Policy 1950-1991: A Cross-Disciplinary Survey of a Contested Public Sphere. EUI Working Paper. RsCAS 2010/80.

Werden, G. J. (2014). Antitrust's Rule of Reason: Only Competition Matters. Antitrust Law Journal, 79(2), 713-759. https://doi.org/10.2139/ssrn.2227097

White House. (2020, February). Economic Report of the President together with the Annual Report of the Council of Economic Advisers. https://www.whitehouse.gov/ wp-content/uploads/2020/02/2020-Economic-Report-of-the-President-WHCEA.pdf

Williamson, O. E. (1968). Economies as an Antitrust Defense: The Welfare Trade-offs. American Economic Review, 58(1), 18-36.

Williamson, O. E. (2002). The Merger Guidelines of the us Department of Justice-In Perspective. $20^{\text {th }}$ Anniversary of the 1982 Merger Guidelines: The Contribution of the Merger Guidelines to the Evolution of Antitrust Doctrine. us Department of Justice. https://www.justice.gov/atr/hmerger

Wilson, C. S. (2019, February 15). Welfare Standards Underlying Antitrust Enforcement: What You Measure is What You Get. Keynote Address at George Mason Law Review 22 $2^{\text {nd }}$ Annual Symposium: Antitrust at the Crossroads? Arlington, Virginia.

$\mathrm{Wu}, \mathrm{T}$. (2018). The Curse of Bigness: Antitrust in the New Gilded Age. Columbia Global Reports.

Zingales, L. (2017). Towards a Political Theory of the Firm. Journal of Economic Perspectives, 31(3), 113-130. https://doi.org/10.2139/ssrn.2999910 